\title{
ЗАВЕРШЕННЯ ПРИВАТИЗАЦІЇ В ЕНЕРГЕТИЦІ ТА ÏÏ ВПЛИВ НА РІВЕНЬ ЕНЕРГЕТИЧНОЇ БЕЗПЕКИ В УКРАЇ̈I
}

${ }^{1}$ Соколовська Н. I., асn.;

${ }^{2}$ Рябцев Г. Л., д-р наук держ. упр., професор;

${ }^{1}$ Україна, Київ, Національна академія державного управління при Президентові України;

${ }^{2}$ Украӥна, Київ, Національний інститут стратегічних досліджень

DOI: https://doi.org/10.31435/rsglobal_ijite/30112018/6207

\section{ARTICLE INFO}

Received 13 September 2018

Accepted 25 November 2018

Published 30 November 2018

\section{KEYWORDS}

public administration, regulation in the energy sector, privatization of energy assets, electricity market, energy security. \begin{abstract}
The article analyzes the influence of privatization, which is the main tool for the formation of market relations in the energy sector. The authors found that as a result of the privatization of energy assets in Ukraine, it was not possible to maintain a balance of interests of the state, business and society. The state monopoly was replaced by oligopoly, consumer sovereignty was not secured, and responsibility for energy security is distributed unevenly between business and government. Because of the lack of coordination of policy objectives, privatization did not use the investment resource for energy development, mechanisms for the return of invested funds, which were tested by world experience, were not involved. Completion of privatization should take place after the adoption of a number of decisions related to the institutional framework for the development of electricity market, the development of privatization conditions and contracts with potential investors, measures to ensure the energy security of the state. Reliability of energy supply in the context of further development of private property in the energy sector will be determined by the effectiveness of state regulation in this area, the ability to prevent uncompetitive behavior of market participants. The delay in moving to the European energy model encourages business entities (including sectored monopolists) to lobby their own projects in the government bodies that contradict the established principles of market functioning. The risk of transforming the transitional measures into permanent ones is no less a threat. At the same time, the incompleteness of the transition from the administrative to the market model of regulation not only hampers the development of the world's best business practices by business entities, but also undermines the credibility of government actions. To remedy the situation, it is necessary to accelerate the formation of the institutional and institutional base that ensures the functioning of the energy market in accordance with its new model; to stop administrative interference of the state in the activity of subjects of energy markets, regardless of forms of ownership; to complete privatization of energy assets; to refuse crosssubsidization; to complete the process of monetization of subsidies. Civil society institutions should become a lever to control management decisions and not to distort the norms of the Law of Ukraine "On the Electricity Market" at the stage of its implementation.
\end{abstract}

Citation: Соколовська Н. І., Рябцев Г. Л. (2018) Zavershennia Pryvatyzatsii v Enerhetytsi ta Yii Vplyv na Riven Enerhetychnoi Bezpeky v Ukraini. International Journal of Innovative Technologies in Economy. 8(20). doi: 10.31435/rsglobal_ijite/30112018/6207

Copyright: (C) 2018 Соколовська Н. І., Рябцев Г. Л. This is an open-access article distributed under the terms of the Creative Commons Attribution License (CC BY). The use, distribution or reproduction in other forums is permitted, provided the original author(s) or licensor are credited and that the original publication in this journal is cited, in accordance with accepted academic practice. No use, distribution or reproduction is permitted which does not comply with these terms. 
Постановка проблеми. Унаслідок приватизаційних процесів в електроенергетиці відбулася трансформація державної монополії в приватну з невизначеною відповідальністю за рівень енергетичної безпеки. Завершення приватизації в енергетиці не в змозі забезпечити ефективну конкуренцію серед виробників і постачальників електроенергії. 3 огляду на це, особливої актуальності набуває розроблення ефективних механізмів державного регулювання в частині забезпечення належного рівня енергетичної безпеки в новій моделі енергетичного ринку.

Аналіз останніх досліджень і публікацій. Теоретичні, методичні й практичні проблеми реформування відносин власності розроблялися в наукових дослідженнях В. Бесєдіна, А. Гальчинського, В. Геєця, В. Голікова, С. Мочерного, О. Пасхавера. Загальні оцінки ефективності процесів приватизації в Україні зроблені також у наукових доповідях О. Кошика, О. Білоцерківця, В. Дубровського. У соціальному вимірі проблему досліджував український соціолог С. Головаха. Натомість особливості приватизаційних процесів в окремих галузях розглянуті лише у поодиноких статтях (В. Лір, О. Рябченко, А. Юрчук).

Метою статті є визначення шляхів вдосконалення механізмів державного регулювання на новому енергетичному ринку задля підвищення рівня енергетичної безпеки України.

Виклад основного матеріалу. Рішення, що стосуються управління суб'єктами господарювання та їхнім розвитком, є надзвичайно ризикованими. Оскільки більшість бізнес-рухів не мають чіткого пояснення, неможливо прописати, які саме управлінські рішення, як саме i коли приймати. Відтак, керівники, які не відповідають за наслідки своїх рішень власним майном, є менш заінтересованими в їхній правильності та вчасності. Уважається, що це і є основною причиною занепаду державних підприємств незалежно від «якості» держави (Геєuь, 2009).

Керуючись цими міркуваннями, відразу після проголошення незалежності Україна розпочала формування приватного сектора економіки. Однак, на відміну від інших галузей, роздержавлення електроенергетичних активів потребувало більш зваженого підходу. Цю вимогу було обумовлено необхідністю значних капітальних інвестицій унаслідок зношеності енергетичного обладнання, основна частина якого експлуатувалася 3 1960-х i була спроектована за нормами 1950-х.

Оскільки одна лише приватизація була нездатна стимулювати інвестиційноінноваційний розвиток галузі, держава мала сприяти формуванню конкурентної інфраструктури та інституційного середовища. Щоб забезпечити виконання цієї умови, у 19961997 рр. було прийнято Закон України «Про електроенергетику» та постанову Уряду «Про забезпечення роботи оптового ринку електроенергії України» (ОРЕ).

Однак, сталося так, що лібералізація енергетики започаткувала ринкові відносини лише де-юре. Де-факто замість посилення конкуренції відбулася концентрація енергетичних активів у декількох приватних учасників ринку, які отримали можливість зловживати своїм домінуючим становищем. До цього призвели такі події.

Приватизація енергетичних активів в Україні відбувалася в декілька етапів. Проте під час вибору напряму й механізмів реалізації перетворень в енергетиці, у тому числі корпоратизації та приватизації підприємств паливно-енергетичного комплексу, не були в повному обсязі враховані стартові умови та особливості перехідного періоду. Оскільки вітчизняні компанії виявилися не здатними конкурувати 3 іноземними інвесторами, перша хвиля приватизації енергоактивів перетворилися на низку штучних банкрутств та/чи рейдерських захоплень.

У 1997-1998 pр. під інвестиційні зобов’ язання було продано пакети акцій від 20 до 45 \% у статутних фондах 9 із 27 обласних енергопостачальних компаній. Із другої половини 1998 р. перевага надавалася некомерційним конкурсам. На цьому етапі, на відміну від першого, було створено умови для покращення фінансового стану обленерго - реструктуризовано борги, запроваджено спеціальну методику тарифоутворення. Держава навіть гарантувала фіксований рівень рентабельності (17\%) для нових власників.

Визначальною проблемою цього періоду стало непорозуміння між Фондом державного майна й Міністерством енергетики України. ФДМУ намагався отримати максимум коштів від приватизації для виконання соціальних зобов’язань державного бюджету. Міністерство наполягало на залученні стратегічних власників, які мали реальні можливості та досвід інвестування. Відсутність компромісу призупинила приватизацію і формування конкурентного ринку. Коштів від приватизації не вистачило й на реалізацію програми реконструкції та модернізації діючих ТЕС. Фактичні витрати на модернізацію та розвиток електричних мереж були більш ніж удвічі меншими від потреби (Кабінет Міністрів України, 2006). 
Оскільки перерозподіл прав власності в енергетиці все більше виходив 3-під контролю держави, у 2004 р. Уряд консолідував державні активи, створивши НАК «Енергетична компанія України» (НАК «ЕКУ»), хоча цим рішенням були ліквідовані навіть формальні ознаки конкуренції на оптовому ринку.

Упродовж 10 років НАК «ЕКУ» контролювала державні пакети акцій енергетичних компаній. Але з 2007 р. Уряд почав поступово вилучати їх зі статутного фонду, передаючи ФДМУ для передприватизаційної підготовки. Оскільки в 2014 р. у статутному фонді НАК «ЕКУ»залишилося лише три активи (78 \% акцій генеруючої компанії «Центренерго», 87 \% Дністровської ГАЕС і 60 \% - Луганськобленерго), компанію було ліквідовано.

За даними авторів, унаслідок трьох етапів приватизації, кінцевими бенефіціарами більшості генеруючих і постачальних компаній стали К. Григоришин (частка в 12 обленерго), О. Бабаков (10), І. Коломойський (6), Р. Ахмєтов (4), І. Суркіс (3) та Ю. Бойко (1). У державній власності залишилися контрольні пакети акцій тільки п'яти обленерго, трьох ТЕС, а також ТЕЦ малої та середньої потужності. Власником інших теплових ГК (окрім «Центренерго») та вугледобувних активів є ДТЕК Р. Ахмєтова.

Відмінність філософії приватизації, що відбулася в Україні та, наприклад, Польщі, демонструє порівняння польської вертикально інтегрованої енергетичної компанії Tauron Polska Energy i ДТЕК. Їхні обсяги продажу в 2016 р. становили \$4,8 млрд і \$6,2 млрд, тоді як кінцевими бенефіціарами були, відповідно, 230 тис. акціонерів і Р. Ахмєтов.

Польська приватизація стала двигуном «шокової терапії». У 1991-1995 рр. у країні приватизували понад 3 тис. державних підприємств, що підштовхнуло розвиток економіки (Бялас, 2016). В Україні ж приватизацію перетворено на «неперервний» процес, ефективність якого є сумнівною.

Цей висновок підтверджується здійсненим Національною комісією що здійснює державне регулювання у сфері енергетики і комунальних послуг (НКРЕКП), у 2014 р. порівнянням надійності електропостачання, якості послуг, рівня розрахунків, кількості скарг споживачів, величини накладених штрафів, стану виконання інвестиційних програм обленерго приватної й державної форм власності в 2010-2013 рр. Його результати не дозволяють зробити однозначний висновок, які компанії працюють краще.

Неефективність приватизації енергетичних активів неодноразово ставала предметом розгляду комітетів Верховної Ради України, які вимагали обгрунтування доцільності та переліку об'єктів приватизації, збереження цілісності майнових комплексів, дотримання конкурентного законодавства, визначення кінцевих бенефіціарів, рівних умов і прозорості конкурсів, дотримання постприватизаційних зобов'язань, цивілізованих форм злиття й поглинання активів на вторинному ринку (Лір, 2015; Фролов, 2018).

На жаль, логіку процесу визначали інші центри прийняття рішень. Унаслідок цього, на енергетичний ринок перетворився на олігополію, в оптовому сегменті ринку конкуренція має формальний характер, а на роздрібному споживачі не отримали економічного суверенітету. За цих умов було неможливо виконувати міжнародні зобов'язання України щодо членства в Енергетичному співтоваристві та імплементації Третього енергетичного пакету СС.

Усе це спонукало владу до суттєвого вдосконалення законодавства, зокрема прийняття у 2017 р. Закону України «Про ринок електричної енергії». Згідно з ним до 1 липня 2019 р. мають відбутися кардинальні зміни в структурі галузі. Усі постачальні компанії мають відокремити функцію розподілу від функції продажу електроенергії, завдяки чому будуть створені передумови для виникнення конкуренції серед постачальників і появи вибору для споживачів.

У розвиток новоприйнятого законодавства, рішеннями НКРЕКП, були запроваджені:

- структура і правила ринку електроенергії (двосторонні договори, ринок «на добу вперед», внутрішньодобовий ринок, балансуючий ринок, ринок допоміжних послуг), система спеціальних обов'язків для забезпечення суспільних інтересів у процесі його функціонування; юридичне та організаційне відокремлення діяльності з розподілу й передачі електроенергії від інших видів діяльності;

- кодекси систем передачі, розподілу, комерційного обліку електричної енергії; ліцензійні умови провадження господарської діяльності з передачі, розподілу, перепродажу електричної енергії, іiі постачання споживачеві, здійснення функцій оператора ринку й гарантованого покупця; правила управління обмеженнями та порядку розподілу пропускної здатності мережі, форма договору про доступ до неї, методика визначення доступної пропускної здатності. 
Запровадження нової моделі взаємовідносин забезпечує відмову від тривалий час існуючої моделі нав'язаної моделі «рентної експлуатації» енергетики України. Поряд 3 тим, створюється нормативне та технічне підгрунтя щодо інтеграції електроенергетичного сектору України до загального ринку ЄС, здійсненні транскордонної торгівлі електроенергією.

Проте зазначені документи не пропонують заходів зі створення конкурентного ринку генерації, де можна досягнути найбільшого ефекту в економії первинних енергоресурсів і вплинути на тарифну складову. Найбільша вада цього сегмента - надвисока концентрація, що призводить до викривлення цінових сигналів на ньому. Високими залишаються бар'єри входження на ринок нових суб'єктів, зокрема, імпортерів.

Невдоволення суспільства діями влади та наслідками приватизації енергетичних активів поглиблюється непрозорістю прийняття рішень, зокрема щодо цін і тарифів. Існуючий рівень капіталізації в енергетиці є вкрай недостатній, про що свідчать численні аварії, перебої в енергопостачанні й дефіцит маневрових потужностей. Звісно, що зростання експлуатаційних витрат і надалі перекладатиметься на споживачів. Така ситуація обумовлена відсутністю в Україні перевірених світовим досвідом механізмів повернення інвестицій на реновацію основних фондів галузі.

Однією з визначальних загроз, що виникли останнім часом, є незавершеність переходу від адміністративної до ринкової моделі регулювання енергетичного ринку. Її найпомітнішим проявом є суттєве відставання в темпах розроблення та ухвалення нормативно-правових актів, що мають бути спрямовані на повноцінну імплементацію положень Закону України «Про ринок електричної енергії» i переходу суб'єктів господарювання на кращі світові бізнеспрактики, базовані на стратегіях неперервності бізнесу й механізмах цивілізованої конкуренції.

Ситуація, коли законом запроваджені нові моделі енергетичних ринків та, водночас, діють елементи застарілого права, що регулюють відносини між їх учасниками, формує сумнів щодо системності практичних дій і сталості політики держави.

Зволікання 3 упровадженням європейської енергетичної моделі спонукає суб'єктів господарювання (у тому числі галузевих монополістів) до лобіювання в органах влади власних проектів, що суперечать ухваленим принципам функціонування ринку. Їхні намагання забезпечити собі на якомога довший період особливі умови господарювання (неринкові ціни й тарифи, державні гарантії чи кредити тощо) загрожує і їм самим, і державі в цілому. Адже проекти, розпочаті сьогодні в рамках чинних взаємовідносин, у майбутньому будуть або зупинені через запровадження нової моделі ринку, або заблокують їі становлення.

Не меншою загрозою є небезпека перетворення вимушених, ухвалених на перехідний період заходів на вкорінені й постійні. При цьому незавершеність переходу від адміністративної до ринкової моделі регулювання не лише стримує опанування найкращих світових бізнес-практик суб’єктами господарювання, але й підриває довіру до дій Уряду.

Щоб виправити ситуацію, необхідно:

- прискорити формування організаційно-інституційної бази, що забезпечує функціонування енергетичного ринку за новою моделлю;

- припинити адміністративне втручання держави в діяльність суб’єктів енергетичних ринків, незалежно від форм власності;

- завершити корпоратизацію та приватизацію енергетичних активів;

- відмовитися від перехресного субсидіювання, завершити процес монетизації субсидій.

Фундаментальною умовою формування сприятливого інвестиційного клімату в енергетичному секторі $\epsilon$ утвердження верховенства права, впровадження незалежного й суворого нагляду у сфері конкуренції, а також завершення приватизації енергетичних активів, за винятком стратегічних. Останнє завдання потребуватиме прискорення реформування енергетичних ринків відповідно до Третього енергетичного пакету, забезпечення стабільності й прозорості господарювання, обмеження втручання держави у функціонування ринків.

Проте терміни виконання цих завдань можуть бути порушені через неналежне координування робіт із запровадження нової структури ринку електроенергії. Попри створення в 2017 р. трьох дорадчих органів (Координаційної ради 3 питань проведення реформ у паливноенергетичному комплексі, Координаційного центру із забезпечення впровадження нової моделі ринку електричної енергії та відповідного Проектного офісу), неузгодженість дій і низький рівень взаємодії між органами державної влади, представниками бізнесу й громадянського суспільства у вирішенні проблем, що виникають, є чи не основним гальмом запланованих змін.

За таких умов, інститути громадянського суспільства мають стати важелем контролю прийняття управлінських рішень і не допускати викривлення норм Закону України «Про ринок 
електричної енергії» на стадії його імплементації. Цим самим буде закладено передумови для створення у сферах природних монополій (транспортуванні й розподілі), а також особливих державних інтересів (когенерації, зберігання природного газу) публічних акціонерних компаній.

\section{Висновки.}

1. Унаслідок приватизації енергетичних активів в Україні склалася несиметрична форма балансу інтересів держави, бізнесу й суспільства. Державну монополію замінила олігополія, не забезпечений суверенітет споживача, відповідальність за енергетичну безпеку розподілена між бізнесом та державою вкрай непропорційно.

2. Через неузгодженість цілей політики приватизація не задіяла інвестиційний ресурс для розвитку енергетики та перевірені світовим досвідом механізмів повернення вкладених коштів.

3. Завершенню приватизації має передувати низка рішень щодо інституційних засад розвитку ринку електроенергії, розроблення приватизаційних умов і договорів 3 потенційними інвесторами щодо інвестиційних зобов'язань і гарантування енергетичної безпеки держави.

4. Надійність енергопостачання в умовах подальшого розвитку приватної власності в енергетиці буде визначатися ефективністю державного регулювання у цій сфері, можливістю запобігти неконкурентній поведінці учасників ринку.

5. Інститути громадянського суспільства мають стати важелем контролю прийняття управлінських рішень i не допускати викривлення норм Закону України «Про ринок електричної енергії» на стадії його імплементації.

\section{ЛІТЕРАТУРА}

1. Геєць, В.М. (2009). Суспільство, держава, економіка: феноменологія взаємодії та розвитку. Київ: НАН України.

2. Кабінет Міністрів України (2006). Енергетична стратегія України на період до 2030 року. http://zakon.rada.gov.ua/go/n0002120-13

3. Бялас, М. (2016). Як відбувалася приватизаиія державних підприємств у Польщі. https://www.eurointegration.com.ua/articles/2016/05/30/7049990/.

4. Лір, В.Е. (2015). Оцінка ефективності приватизації енергетичних компаній в аспекті збалансування інтересів держави, бізнесу та суспільства. Економіка і прогнозування, 1, 7-22.

5. Фролов, П.В (2018). Приватизаиія в Україні: ретроспективи та перспективи. https://dt.ua/.../privatizaciya-v-ukrayini-retrospektivi-ta-perspektivi-272273_html/. 